\title{
USING WORDLESS PICTURE BOOK AS A CONTRIBUTIVE LEARNING MEDIA TO ENHANCE THE STUDENTS' WRITING ABILITY
}

\author{
Khadijah Maming, Irmayanti, Rafi'ah Nur \\ Universitas Muhammadiyah Parepare \\ Email: khadijahmaming@gmail.com
}

\begin{abstract}
This research aims to know enhancement the students' writing ability by using wordless picture book as a contributive learning media. The benefits of using wordless picture book show that the students enhance their writing ability and create their creative writing and thinking skill. The researcher applied quasi-experimental method, with two groups namely experimental and control class. The experimental class consists of 30 students and control clas consists of 30 students. The subjects of the research were 60 students from two classes taken from students of SMP Negeri 10 Parepare. The research instrument was writing test in which the comparison of pre-test and post-test decided the enhancement of the students' writing ability. The results of the data analysis showed that the students' writing ability getting significantly improvement. It was proved by the mean score of pre-test was 46.93 and the post-test was 80.00 . It indicates that the use of wordless picture book can enhance the students' writing ability at SMP Negeri 10 Parepare. Besides, after analyzing the data by using the $\mathrm{t}$-test formula, the result of $\mathrm{t}$-test value in post-test was 6.02 and $\mathrm{t}$-table value was 1.671. It meant that the $\mathrm{t}$-test value was higher than $\mathrm{t}$-table value. It clarified $\mathrm{H}_{1}$ was accepted and $\mathrm{H}_{0}$ was rejected and the students who were taught by using wordless picture book were better than the students who were taught by using wordless picture book.
\end{abstract}

Keywords: Wordless Picture Book, Learning Media, Enhancement, Students' Writing Ability

\section{INTRODUCTION}

Mastering English is a need for every person for who was be a part of an international relationship because English is a tool of international communication. According to Collins (2005), Lee, Han and Mc Kerrow (2010), having "good” English language proficiency means being part of a developed word. It can be seen in an international conference where English is used as a tool of communications. More mastering English, it was be easy to communicate, whereas if the mastering of English is low so we find difficulty in communicating. 
Therefore, it is necessary to master English. Considering the previous reason, it is very important to give the concern to enhance the mastery of English as well as in Indonesia. Especially in writing, it is one of way for the author to express their idea. Besides, writing is also the way to communicate. As the productive skill, writing has some component is that should be noticed for authors. That's way writing is something that very complex. Because the complexity, writing activity is not easy, even most of the people consider that it is difficult. Jacobs and Small (2003) concern the components of writing consist of content, organization, grammar, vocabulary, and mechanics. The students are supposed to have good writing competence by paying the components of writing. These writing components are regarded very important items in producing an essay and composition. Hence, a writer should master the writing components in writing activities.

This description also supported by Heaton in his book "Writing English Language Test" (1975) that writing skills are more complex and difficult to teaching, requiring, and mastering not only of grammatical and rhetorical devices but also conceptual and judgment, because of the difficulties of writing, some effort have been done to solve the problem. The main objective is to make the writing become easier to learn for the students.

The reasons were proved in SMP Negeri 10 Parepare which became the object of research. The researcher found some data from observation in this school. The researcher found that writing is very difficult skills among four compulsory skills. It is found that most of the students' score only got 57 and it is categorized very poor based on the classification of Dirjen Pendidikan Dasar dan Menengah (2005) that is 75 . Indirectly students also informed that they were difficult in mastering the writing skills. The students' weakness is they difficult to find out their ideas. Besides, they got obstacle towards teachers' media in teaching writing, like as the method is not appropriate to teaching writing.

One of the various potential strategies to teach writing is wordless picture book. Wordless picture book as the name of a book without the word, so it can stimulate the reader to illustrate the meaning based on the picture. The wordless picture book also guide the students to develop and express their idea in writing by looking at the picture. According to Arif and Hashim ( 2008 ), the wordless picture book is unique in that its content can be communicated solely through illustrations of the pictures. It communicates messages; the wordless picture book can be enhanced to communicate as well. The objective research of this study is to know the effectiveness of the use of Wordless Picture Book is able to enhance the students' writing ability at SMP Negeri 10 Parepare.

There are several authors have explained the concept of wordless picture book. Some of them, Arizpe (2013) defined that Wordless Picture Book as a text where the visual image carries the weight of the meaning. When engaging with wordless picture book, students are encouraged to interpret the messages, and communicate their understanding orally, visually, or in writing. Geyzer (2006) stated writing is the way students who lack self-confidence express themselves and writing also allows students 
to practice rules of grammar and examination techniques. Harvey and Goudvis (2000) confirmed that wordless picture book media has a purpose to sketch visual images of text to aid in memory and recall the story. Besides, Kucer and Cecilia (2005) stated that wordless picture book is one of the means providing writing experiences for middle and high school students. Additionally, Day (2007) also defined that wordless picture book media is visualized to fill missing information. Based on the previous opinion, the researcher concluded that wordless picture book is one of the media to recall the story by visualizing what the meaning of the picture. The wordless picture book is also a way to communicate our understanding orally or writing by the picture.

Kucer and Cecilia (2005) then enriched their explanation with the procedures of wordless picture book as follow:

a. The teacher introduces the wordless picture book for the students and informs them that the wordless picture book enables the readers to invent their own story lines.

b. The teacher asks the students to think about the wordless picture and invite them to express their ideas orally.

c. Then, the teacher guides the students to write what they think about the wordless pictures. Or, they can write the sentence underneath the picture on the transparency. It should be done from the first page of the book.

d. The student must write the sentences for all picture and after completing it, they can read the book in complex form.
Then, Ellery (2009) adds an argument about the steps in applying the wordless picture book in teaching as below:

a. The teacher discusses the way the author expresses their ideas with students. The teacher tells them that wordless picture book is an example of the author's expression.

b. The teacher informs the students that in wordless picture book, the author uses the picture illustrations to tell his/her story.

c. The teacher distributes the wordless picture book for the students and asks them to talk about the picture.

d. Ask the students to prepare slip of paper, index cards, sticky notes for writing the words that might accompany the picture. This can be done individually or in small groups.

e. Finally, after all, text have been written by the sentences, the students are provided to share their complete story in front of the class.

Based on the procedure given by the experts above, the researchers combined the implementation from Ellery (2009) and implementation from Kucer and Cecilia (2005) to be applied in teaching writing. Wordless picture book is regarded as a learning media that can contribute to enhance the students' writing ability. This learning media can be good tool in assisting process of teaching and learning writing.

From others view of points, the researchers present the strengths of wordless picture book showed a marked enhancement in students writing 
skills. Two of them are Huang (2009) stated that by using wordless picture book the students enhanced their sequencing skills by retelling the story in chronological order with details and consistent use of time-order words. The benefits of using wordless picture book show that students can enhance their visual literacy and oral to written expression, promote their creative writing and thinking skills, and enhance their enjoyment of the writing process.

The same statement explored in Pictures as a Tool for Sentence Construction (2009) suggested the usage of wordless picture book as a way to enhance English writing. He claimed that the benefits of using wordless picture book are that pupils are able to enhance their visual literacy, oral and written expression, enhance their creativity in writing and thinking skills as well as making learning interesting. Based on the previous reason, the research concludes that teaching writing by using wordless picture book can enhance the students writing skill, it also tries students to critical thinking skill, promotes creativity and imagination, enjoys in the writing class.

In teaching English, method, media, technique and media are very important. So that, the teacher should master the media especially in teaching English Writing. A good media in teaching writing can enhance the students ie interest in learning English and can facilitate the students to understand the material. In this research, the researchers are interested in using wordless picture book media to enhance writing ability of the students at SMP Negeri 10 Parepare.

\section{METHOD}

The research design used in this research was quasi experimental design. In this case, there were two groups involved namely experimental group and control group. The treatment implemented in experimental groups was the use of wordless picture book while the control group was treated by using word picture book. The same pretest and posttest were distributed to these both group.

The subjects of this research was 60 students where they were divided in two groups. 30 students were placed in experimental group and also 30 students were placed in control group. They were taken from students of SMP Negeri 10 Parepare. By applying cluster random sampling to decide the sample of this research, it was taken from class VII 1 as experimental group and VII 2 as control group.

The instrument of the research was a writing test. The researchers focused on writing descriptive text to enhance the students' writing ability. The both of class asked to make an essay in 100-150 words within 80 minutes, which appropriated with generic structure of the descriptive text; namely identification, and description. The topic gave is "Pictures". The picture was given to the different theme in the first meeting until the fourth meeting, namely activity, animals, someone, and hobbies.

The hypothesis of the research consists of two hypothesis, namely Null Hypothesis $\left(\mathrm{H}_{0}\right)$ and alternative Hypothesis $\left(\mathrm{H}_{1}\right)$, where Null Hypothesis $\left(\mathrm{H}_{0}\right)$ means that here is no any significance different between the writing ability of the students who are taught by using wordless picture book and the writing abilty of the students who are taught by using word 
picture book, while Alternative Hypothesis $\left(\mathrm{H}_{1}\right)$ means that there is a significance different between the writing ability of the students who are taught by using wordless picture book and the writing ability of the students who are taught by using word picture book.

In the process of giving treatment to the both of groups experimental and control, the researchers run the sequence of learning activities in writing class. For experimental class, teaching process conducted by using wordless picture book. In the process of learning, students were stimulated by using wordless picture book. Firstly, students were asked to visualize their idea by writing the brainstorm in the sticky note. The students may write the word, phrase until the sentence. Then, they constructed their paragraph in the student's task that have prepare by the researchers. For control class, the students were asked to write their idea by word picture book. The process of learning is almost same in experimental class. Something only that difference is the media, when in the control class by using wordbook. The students were not stimulated because the students can get the idea by reading the book.

\section{FINDINGS AND DISCUSSION}

The findings of the study concluded that wordless picture book can enhance the students' writing ability at SMP Negeri 10 Parepare. It is proved by the difference between pre-test and a posttest result of the final score of the students' writing. Where the result of the $t$-test in post-test is 6.02 while the $\mathrm{t}$-table is 1.671 . It shows that t-test value is higher than $\mathrm{t}$-table value. By correlating this result with the testing hypothesis, it indicates that null hypothesis
$\left(\mathrm{H}_{0}\right)$ is rejected and the alternative hypothesis $\left(\mathrm{H}_{1}\right)$ is accepted. In addition, if the mean score of pre-test and post-test are imported to the score classification of Dirjen Pendidikan Dasar dan Menengah (2005) that is 75 , it shows that the mean score of the pre-test (46.93) is in poor score classification and the posttest $(80.00)$ is in good score classification with the mean difference is (33.07). Beside the result from the data the proved that the treatment is succesfully can be show in the process of learning, where the students feeling enjoy because basically students prefer picture that can make them interested to learn. It brightly shows that the teaching writing to the students at SMP Negeri 10 Parepare using wordless picture book is better.

Moreover, the researcher confirmed two benefits of using wordless picture book. These benefits included enhancement the writing ability and promotion of creative writing and thinking skill. The enhancement the writing ability of the students also can be seen in learning process. By wordless picture book the students constructed their idea as pure from their thinking and stimulated from that book. In the other word, the students can do writing activity by their own word. It means that the students' writing getting enhancement.Based on the result after giving the treatment indicate that the students' writing ability were taught by using wordless picture book is getting enhancement. It can be seen through the mean score of student that increase to 46.93 to 80 . It means that the enhancement is become 33.07.

In addition, this enhancement shows that wordless picture book can enhance the students' writing ability at SMP Negeri 10 Parepare. Therefore, 
the researchers draw the benefits about wordless picture book, namely the students are enjoyable in learning process and interested in learning by using wordless picture book, and also the atmosphere of learning is more active in writing class. The results of this research supported statement from Huang (2009) in which in his research found three benefits of using of wordless picture book, those are included enhancement of enjoyment of the writing process, promotion of creative writing and thinking skill, and the fostering of cooperative learning. The similarity of this research were using wordless picture book and apply in teaching writing, while the difference of this research were had different object and sample research. Promotion of creative writing and thinking skill can be seen in writing class, after given the treatment, in this case, the students learning by the wordless picture book. By this practice, students had a chance to develop logic in their story development. The students also had a chance to promote their writing in front of the class. The creative writing and thinking skill they got from the wordless picture book which stimulate students to though what the meaning of the story in that book.

This research finding also supported Huang (2009) that found that by using wordless picture book, beside enhancement the students' writing abilty also as the opportunity for students' to promote their creation, in this case their writing result by using wordless picture book. This research findings also supported Marble's research (2012) about wordless picture book can help develop a student's writing process and should be used with variety students. This method also makes students able to create ideas and add details to their writing based on the illustration found within the wordless picture book. In this research, he also using wordless book as media in writing class, but the difference is he applied the method in variety student while the researcher using the method to students in junior high scholl, specially in SMP Negeri 10 Parepare.

Additionally, it also supported statement from Setiani, Sudarsono, and Husin (2013) said that wordless picture book can stimulate the students to express her/his ideas freely without having to face the reader directly, also can be used to motivate and interest from student. It can be shown in the process of learning, while the researcher stimulated the students by using wordless picture book to construct their writing . The similarity of this research were using wordless picture book in the same skill, those are writing skill. The researcher also applied descriptive text to teaching writing, while the difference was had different sample in the research.

Furthermore, the research findings supported statement of Arizpe, E. (2013) in his study found that engagement and awareness of the demands of the wordless picture book can develop and increase through collaborative reading with peers or adult media depending on the context, the aims, and strategies used in approaching and the text. It can be show that the students able to making the meaning by reading the wordless picture book, in this case the students did not read by the text but only reading by the meaning of the book. Specially in this research, the difference among the other finding is the applied using wordless book in reading skill, while the findings before is using wordless picture book in writing skill. 
Refering to a result of this study it can be stated that wordless picture book can be used as media to help students' English writing. While wordless picture book are explained as "pure" picture book ( Hilman, 1995). The students are read by means of illustrations and the story depends on what the readers visualize. Picture without text help students creates their own story using the picture they see rather that the word they read.

Applying the treatment, the researcher introduced the class with explaining about the material what the students was learned than the researcher explained about how to learn by the wordless picture book. The first meeting, socialize to the students that wordless picture book are one of the media which use by an author to write their ideas. Then, the researcher explained about the descriptive and how to write descriptive text by using wordless picture book with given different theme in every meeting. In the second meeting, the researcher asks the students to write by wordless picture book that provides by the researcher. This activity until the fourth meeting.

Furthermore, the enhancement of the students' writing ability also can be seen by the result of the post-test score which is higher than pre-test. The researcher concluded that the students' writing ability in the experimental class was enhanced with mean scores 80.00 categories as good classification score. It means that the score in post- test were better than the score in pre- test. After applying in t-test formula, the result computation of t-test was 5.29 for pre-test and 6.02 for post- test. If we consulted with the $t$-table value with the degree of freedom (df)
$\mathrm{N}_{1}+\mathrm{N}_{2}-2$ ) were significantly different. This indicates that the null hypothesis $\left(\mathrm{H}_{0}\right)$ is rejected and the alternative hypothesis $\left(\mathrm{H}_{1}\right)$ is accepted because t-test value (6.02) is greater than $\mathrm{t}$-table value (1.671). It means that the students of SMP Negeri 10 Parepare could enhance their writing ability by using wordless picture book.

\section{CONCLUSION}

Based on the research result, that t-test value is higher than t-table value, it is proven that null hypothesis $\left(\mathrm{H}_{0}\right)$ is rejected and the alternative hypothesis $\left(\mathrm{H}_{1}\right)$ is accepted. It is means that the writing ability of the students' at SMP Negeri 10 Parepare can be enhanced by using wordless Picture Book. Beside the result from the data the proved that the treatment is succesfully can be show in the process of learning, where the students feeling enjoy because basically students like picture that can make them interested to learn.

The researcher gives some suggestions for some elements related to this research, those are: education word, english teacher, the students, and the next researcher. Firstly, the curriculum should be able to information for developing teaching media, especially in teaching writing. Also the media that design should be more interesting. Secondly, teacher should be able to use of wordless picture book as one way in teaching English to enhance the students' writing ability. The teacher also should be creative in making and giving the material in conducting the teaching and learning the process. Besides, the teacher shuold apply some of the teaching method in order the students more enjoyable in comprehending the material. Thirdly, The students should spend a lot 
of time to practice writing by using wordless picture book with their friends. Last, the researche inform that wordless picture book is one of the alternative media which can be used as a media by another researcher in English beside writing skill.

\section{REFERENCES}

Arif, M. M and Hashim, Fatimah. 2008. Reading from the Wordless: A Case Study on the Use of Wordless Picture Book. English Language Teaching Journal Vol.1, No.1. (pp.121-126). Malaysia.

Arizpe, E. 2013 Meaning-Making from Wordless (Or Nearly Wordless) Picture Book: what Educational Research Expects and What Readers Have to Say. Cambridge Journal of Education, 43 (2). ISSN 0305-764X.

Cushing, Weigle Sara. 2002. Assessing Writing. England: Cambridge University.

Day, Hanne. 2007. Talking about Wordless Picture Book: A Tutor Strategy Supporting English Language Learners. London: UPS

Department Pendidikan Nasional. 2005. Peraturan Direktorat Pendidikan Dasar dan Menengah. Nomor 506/c/Kep/2004. Tentang Penilaian Perkembangan Anak Didik. Jakarta: Department Pendidikan Nasional.

Ellery, Valerie. 2009. Creating Strategies Readers: Technique for Developing Competency in Phonemic Awareness, Phonics, Fluency, Vocabulary, and Comprehension. New York: International Reading Association Inc.
Geyzer, J. P. 2006. English to the Word.: Teaching Methodology Made Easy. Selangor: August Publication Sdn Bhd.

Harvey, Stephanie and Anne Goudvis. 2000. Strategies that Work: Teaching Comprehension for Understanding and Engagement. New York: Pembroke Publishers.

Heaton, J. B. 1975. Writing English Language Test. London : Longman.

Hillman, J. 1995. Discovering Children's Literature. Englewood Cliffs, NJ: Prentice-Hall.

Huang. 2009. Writing wordless picture book to facilitate English writing. ASEAN EFL Journal.Vol.8 August.

Jacobs, G.M and Small. J. 2003. Combining Dictogloss and Cooperative Learning to Promote Language Learning, retrieved on from http://www.readingmatrix.com/ article.pdf on December 20th (2007).

Kucer, Stephen B. and Cecilia Silva. 2005. Teaching the Dimensions of Literacy. New York: Routledge.

Marble. 2012. How Do Wordless Picture Book Help Develop Writing for All Students?. New York: Pembroke Publisher.

Mc. Kerrow. 2010. Introduction to International Relationship. The University of London.

Setiani, Sudarsono, Husin. 2013. Using a Unworded (Wordless) Picture to Teach Descriptive Text Writing Skill. Teacher Training Education Faculty of Tanjungpura University in Pontianak. E-mail.ety. setiani.es@gmail.com. 